\title{
Hepatitis C Virus Treatment Revolution: Eastern European Story
}

\author{
Carol Stanciu ${ }^{1, *} ;$ Anca Trifan ${ }^{1,2}$ \\ ${ }_{1}^{1}$ Emergency University Hospital, Institute of Gastroenterology and Hepatology, Iasi, Romania \\ ${ }^{2}$ University of Medicine and Pharmacy, lasi, Romania \\ ${ }^{*}$ Corresponding Author: Carol Stanciu, Emergency University Hospital, Institute of Gastroenterology and Hepatology, Iasi, Romania. Tel: +40-722306020, Fax: +40-232264411, \\ E-mail:stanciucarol@yahoo.com
}

Received: April 1, 2015; Accepted: June 6, 2015

\begin{abstract}
Hepatitis C can be cured and even eradicated by new “revolutionary" treatments. However, at present exorbitant prices, Eastern European countries cannot afford the new treatments, while in western rich and developed countries (e.g. Germany and France) they are already available. Concerted efforts of governments, public health officials, and the community at large, are needed to negotiate agreements with pharmaceuticals companies to make the new treatments accessible and affordable. When science has demonstrated that hepatitis $\mathrm{C}$ can be cured, it would be unforgivable if millions of infected patients from eastern parts of the continent were denied access to new treatment on grounds of high prices and financial constraints.
\end{abstract}

Keywords: Hepatitis C; Treatment; Access

\section{Introduction}

The treatment of chronic Hepatitis C Virus (HCV) infection has seen tremendous advances over just a quarter of a century, since 1989 when the virus was discovered (1), to the present day, when the infection can be cured, which is something quite unique in viral infections and even in modern medicine (2). The Interferon (IFN) monotherapy used in the late 1980s (3) was followed by dual therapy (recombinant IFN alpha + ribavirin) at the end of the 1990s (4), then, in 2001, by Pegylated Interferons (Peg-IFN) + ribavirin (5), and the use of 1st generation Direct Acting Antivirals (DAAs) in 2011 (6, 7), culminating with a new wave of DAAs in 2013 (8), administered in different combinations without interferon. These therapeutic improvements were presented in the hepatogastroenterology literature as "milestones", "a new era", and nowadays as "revolutionary".

Dual therapy with PegIFN + ribavirin is currently the only treatment for chronic HCV infection in Romania as well as in other Eastern European countries, where genotype 1 is present in over 95\% of infected patients, and the rate of Sustained Virological Response (SVR) is around 50\% or even less (9). Triple therapy (PegIFN + ribavirin + telaprevir or boceprevir) was approved in 2011 by the Food and Drug Administration (FDA) and the European Medicines Agency (EMA), yet it was not made available in Romania and some neighboring countries. However, triple therapy had only a short lifetime from its launching to the moment when it was not anymore recommended both by the European Association for the Study of the Liver (EASL) and the American Association for the Study of the Liver Disease (AASLD) (2014), mainly because of the arrival of the new "revolutionary" highly effective and safe DAAs on the market.

\section{Treatment Revolution}

The year 2013 announced an unprecedented therapeutic victory with several new DAAs having different viral targets, including NS3 protease inhibitors, nucleoside/ nucleotide analogues and non-nucleoside inhibitors of the RNA-dependent polymerase and NS5A inhibitors, some already approved by the EMA and/or FDA in 2013 (sofosbuvir and simeprevir) and 2014 (daclatasvir; Abbvie's Viekira Pak (ombitasvir and ritonavir boosted paritaprevir plus dasabuvir); Harvoni (ledipasvir + sofosbuvir)), with more to expect in 2015 and in the next two to three years. All these new DAAs were proved to be amazingly efficient (90\% - 100\% SVR), safe, and well tolerated, while all oral, IFN-free combinations cure and even eradicate HCV infection $(10,11)$.

A "contagious" enthusiasm spread among the authors of hundreds of articles; almost all with opening statements such as "the advent of the new DAAs has revolutionized the treatment of HCV infection", and some with closing remarks as "HCV could be cured and even eradicated". According to the dictionary, "to revolutionize" means "to completely change the way something is done, thought about, or made" (Macmillan English Dictionary). Does this mean that the standard care of dual-

Copyright (C) 2015, Kowsar Corp. This is an open-access article distributed under the terms of the Creative Commons Attribution-NonCommercial 4.0 International License (http://creativecommons.org/licenses/by-nc/4.0/) which permits copy and redistribute the material just in noncommercial usages, provided the original work is properly cited. 
and triple-therapy should be dropped? Logically and ethically, once agreed that HCV infection can be cured and even eradicated with the new DAAs treatment, the answer is "YES" and it is strongly sustained by professional societies' guidelines (AASLD and EASL).

\section{The Situation in Eastern Europe}

What does this therapeutic "revolution" mean for us and other Eastern European countries? Can we afford it, considering the present exorbitant prices? For sofosbuvir, the initial cost was 84000 USD per 12-week course, and 1000 USD per pill, making it one of the most (if not the most) expensive drug product ever marketed. At such prices, our country, other Eastern European countries and many other low- and middle-income countries from all over the world, where the HCV pandemic is mainly concentrated ( $85 \%$ of the patients) cannot afford the new treatments.

In Europe, there have always been significant socioeconomic disparities between some western "rich" countries (e.g. Germany, France, UK etc.) and eastern lower middle-income countries (e.g. Romania, Bulgaria etc.). All of us, physicians and patients, still remember the grim times of the Berlin wall, symbol of the differentiation made, among other things, in terms of health care facilities, including the access to new treatments, between Eastern and Western European countries. Paradoxically, 25 years after the political revolution that led to the fall of the Berlin wall, the therapeutic revolution has now raised a new "wall" for eastern European patients, restricting their access to therapy, while in some western countries, such as Germany or France, with large health budgets, new treatments are already available. Even with a very strong will from the part of the governments, most of the Eastern European countries could not afford to purchase the new treatments at the current price for all who need it, simply because this would mean spending their entire annual health budget. Consequently, the gap in the therapeutic approach will widen between the rich countries in Western and Northern Europe and those in the East.

No one will understand and accept the high sale price of the new DAAs, despite producers' attempts to justify it (costly research programs etc.), considering that manufacturing costs are very low (between 68 and 136 USD for sofosbuvir, 10 and 30 USD for daclatasvir, and 130 and 270 USD for simeprevir). Unless companies producing DAAs, make their drugs widely affordable, HCV infected patients from Eastern Europe will never benefit from equitable access to treatment. Unfortunately, Gilead's voluntary licensing with Indian-based generic companies, allowing the production and sale of their new DAAs, sofosbuvir and ledipasvir, in 91 countries (mostly low-income and only few middle-income countries), excluded all Eastern European countries from receiving affordable treatment (12).

\section{What Should Be Done?}

A common attitude together with concerted efforts of Eastern European governments, non-governmental organizations, public health officials, clinical care providers, patient advocacy groups, media representatives and the community at large are needed to negotiate agreements with pharmaceutical companies to make these new lifesaving treatments accessible and affordable (13). The situation of HCV therapy today is similar to the debates in 2000 on human immunodeficiency virus infection and acquired immune deficiency syndrome (HIV/AIDS) treatment, when the initial price of triple antiretroviral therapy was very high (unaffordable for millions of infected people). Over the last 15 years, generic competition has driven prices down by $99 \%$, and this should be a lesson for today's battle against the exorbitant prices of the new HCV treatment (14). Egypt has shown that commitment from the part of the government and tough negotiations with Gilead brought them a $99 \%$ discount on the US price of sofosbuvir(15).

\section{Towards Medical Triumph for All}

Hepatitis C Virus infection can be cured and even eradicated by new treatments and this undeniable truth has become more contagious than HCV infection itself, to such a degree that nobody can stay in its way. Rarely, if ever, has mankind seen a curative therapy for a chronic viral infection as for hepatitis C. It would be unimaginable and unforgivable for the present generations if this medical triumph would be wasted and HCV patients, as citizens of low- and middle-income countries, are left excluded from new treatments on grounds related to high prices and financial constraints.

We, physicians and patients, from both Eastern and Western Europe, share the same dreams and goals: to cure and eradicate hepatitis C. In other words, we should all be treated like in a real family (Gens Una Sumus) and have equal access to new therapy throughout Europe and ideally, worldwide.

\section{Authors' Contributions}

Anca Trifan participated in the concept and the design of this manuscript, collected the data, coordinated the manuscript, and drafted and revised it critically. Carol Stanciu contributed to the concept and design of this manuscript, analyzed the data, coordinated the manuscript drafting and revised it critically. Both authors read and approved the final version of the manuscript.

\section{References}

1. Kuo G, Choo QL, Alter HJ, Gitnick GL, Redeker AG, Purcell RH, et al. An assay for circulating antibodies to a major etiologic virus of human non-A, non-B hepatitis. Science. 1989;244(4902):362-4.

2. Chung RT, Baumert TF. Curing chronic hepatitis C--the arc of a medical triumph. N Engl J Med. 2014;370(17):1576-8.

3. Davis GL, Balart LA, Schiff ER, Lindsay K, Bodenheimer HJ, Perrillo RP, et al. Treatment of chronic hepatitis $\mathrm{C}$ with recombi- 
nant interferon alfa. A multicenter randomized, controlled trial. Hepatitis Interventional Therapy Group. $N$ Engl J Med. 1989;321(22):1501-6.

4. Poynard T, Marcellin P, Lee SS, Niederau C, Minuk GS, Ideo G, et al. Randomised trial of interferon alpha2b plus ribavirin for 48 weeks or for 24 weeks versus interferon alpha2b plus placebo for 48 weeks for treatment of chronic infection with hepatitis $\mathrm{C}$ virus. International Hepatitis Interventional Therapy Group (IHIT). Lancet.1998;352(9138):1426-32.

5. Fried MW, Shiffman ML, Reddy KR, Smith C, Marinos G, Goncales FJ, et al. Peginterferon alfa-2a plus ribavirin for chronic hepatitis C virus infection. N Engl J Med. 2002;347(13):975-82.

6. Poordad F, McCone JJ, Bacon BR, Bruno S, Manns MP, Sulkowski MS, et al. Boceprevir for untreated chronic HCV genotype 1 infection. N Engl J Med. 2011;364(13):1195-206.

7. Jacobson IM, McHutchison JG, Dusheiko G, Di Bisceglie AM, Reddy $\mathrm{KR}$, Bzowej NH, et al. Telaprevir for previously untreated chronic hepatitis C virus infection. N Engl J Med. 2011;364(25):2405-16.

8. Gane EJ, Stedman CA, Hyland RH, Ding X, Svarovskaia E, Symonds WT, et al. Nucleotide polymerase inhibitor sofosbuvir plus ribavirin for hepatitis C. N Engl J Med. 2013;368(1):34-44.

9. Marcellin P, Cheinquer H, Curescu M, Dusheiko GM, Ferenci P,
Horban A, et al. High sustained virologic response rates in rapid virologic response patients in the large real-world PROPHESYS cohort confirm results from randomized clinical trials. Hepatology. 2012;56(6):2039-50.

10. Ward JW. Hepatitis C virus: the 25-year journey from discovery to cure. Hepatology. 2014;60(5):1479-82.

11. Pawlotsky JM. Hepatitis C treatment: the data flood goes on-an update from the liver meeting 2014. Gastroenterology. 2015;148(3):468-79.

12. GILEAD . Chronic hepatitis $C$ treatment expansion generic manufacturing for developing countries. 2014. Available from: http://www. gilead.com/ /media/Files/pdfs/other/HCVGenericAgreementFactSheet.pdf.

13. Esmat G. Hepatitis C in the Eastern Mediterranean Region. East Mediterr Health J. 2013;19(7):587-8.

14. Phelan M, Cook C. A treatment revolution for those who can afford it? Hepatitis C treatment: new medications, profits and patients. BMC Infect Dis. 2014;14 Suppl 6:S5.

15. Flick M, Hirschler B. Gilead offers Egypt new hepatitis C drug at 99 percent discount.: Reuters; 2014. Available from: http://www.reuters.com/article/2014/03/21/us-hepatitis-egypt-gilead-sciencesidUSBREA2K1VF20140321. 